\title{
Effects of six weeks consumption of coconut milk oil on vascular functions and fasting blood glucose and lipid profile in middle-aged male rats
}

\author{
Jomkarn Naphatthalung ${ }^{1,4}$, Pilaipan Chairuk ${ }^{1,4}$, Kanyanatt Kanokwiroon ${ }^{2,5}$, Nisaudah \\ Radenahmad $^{3}$, Chaweewan Jansakul ${ }^{1,4}$
}

${ }^{1}$ Faculty of Traditional Thai Medicine, Prince of Songkla University, Hat-Yai, 90110, Thailand; ${ }^{2}$ Department of Biomedical Sciences, Faculty of Medicine, Prince of Songkla University, Hat-Yai, 90110, Thailand; ${ }^{3}$ Department of Anatomy, Faculty of Science, Prince of Songkla University, HatYai, 90110, Thailand; ${ }^{4}$ Natural Product Research Centre of Excellence, Prince of Songkla University, Hat-Yai, 90110, Thailand; ${ }^{5}$ The Excellent Research Laboratory of Cancer Molecular Biology, Prince of Songkla University, Hat-Yai, 90110, Thailand

Corresponding author: Chaweewan Jansakul, $\mathrm{PhD}$, Faculty of Traditional Thai Medicine, Prince of Songkla University, Hat-Yai, 90110, Thailand

Submission Date: October $6^{\text {th }}, 2019$. Acceptance Date: November $28^{\text {th }}, 2019$. Publication Date: November $30^{\text {th }}, 2019$

Citation: Naphatthalung J., Chairuk P., Kanokwiroon K., Radenahmad., Jansakul C. Effects of six weeks consumption of coconut milk oil on vascular functions and fasting blood glucose and lipid profile in middle-aged male rats. Functional Foods in Health and Disease 2019; 9(11): 719-734. DOI: https://doi.org/10.31989/ffhd.v9i11.665

\begin{abstract}
Background: Coconut milk consumption in middle-aged male rats can cause increased blood vessel endothelial nitric oxide synthase (eNOS) and cystathionine- $\gamma$-lyase (CSE) protein expression, and decreased fasting blood glucose.
\end{abstract}

Objective: The present study aimed to investigate whether coconut milk oil (CO), the major constituents of the coconut milk, was responsible for those effects.

Methods: $\mathrm{CO}$ was isolated from dried fresh coconut milk and gavaged ( 1 and $3 \mathrm{ml} / \mathrm{kg}$ ) to middleaged male rats for 6 weeks. Animal body weight and food intake, internal organ weight, blood biochemistry, lipid profile, basal blood pressure and heart rate and vascular functions were investigated.

Results: In comparison to a distilled water control group, no differences were observed in any of the parameters studied in the group fed $1 \mathrm{ml} / \mathrm{kg}$ of CO except for an increase in retroperitoneal fat accumulation. Feeding $3 \mathrm{ml} / \mathrm{kg}$ of $\mathrm{CO}$ caused decreased fasting blood glucose, plasma alkaline phosphatase and blood urea nitrogen and liver cell lipid accumulation, but increased 
retroperitoneal fat tissue. It also caused decreased maximal contractile response of endotheliumintact thoracic aortic rings to phenylephrine although the effect disappeared in the presence of $\mathrm{N}$ nitro-L-arginine (L-NA) or removal of the endothelium. DL-propargylglycine together with L-NA caused a higher contraction to phenylephrine in the CO-treated groups than in the control group. It also caused an increase in vasodilatation to acetylcholine, but not to glyceryl trinitrate, of the phenylephrine pre-contracted aortic rings. CO treatment caused increased vascular wall eNOS and CSE protein expression.

Conclusion: $\mathrm{CO}$ at a dose of $3 \mathrm{ml} / \mathrm{kg}$ causes some decrease in cardiovascular risk factors in middleaged male rats, although the amount of $\mathrm{CO}$ consumption should be limited as it caused an increase in retroperitoneal fat.

Keywords: Coconut oil; blood vessel; liver lipid; $\mathrm{NO} ; \mathrm{H}_{2} \mathrm{~S}$

Animal Ethic No: Ref. 06/57

\section{BACKGROUND}

Cardiovascular disease is the leading cause of death globally. Its etiology is multifactorial and unhealthy nutrition is one of the main risk factors. Coconut, Cocos nucifera, is one of the most economically important palm species and is cultivated mainly for the nutritional endosperm from which coconut milk and coconut oil are the main products [1]. Coconut milk is used as a common culinary ingredient and coconut oil is used as a cooking oil in many tropical cuisines, most notably those of Southeast Asia, as well as in Brazilian, Caribbean, Polynesian, Indian and Sri Lankan cuisines [2]. The main constituents of coconut milk are lipids (coconut oil, 41.5\%) with a small amount of carbohydrates (5.2\%) and proteins (4.5\%) [3]. However, some consumers are reluctant to consume coconut products since its main constituent is saturated fatty acids $(40-60 \%)[3,4]$, which is considered to be an atherogen and thus potentially harmful with respect to the development of atherosclerosis in humans. Thus far, however the cardiovascular risk of the consumption of coconut products is still a matter of controversy.

There are two types of coconut oil, copra or refined coconut oil prepared from the mechanical compression of sun-dried coconut, and virgin coconut oil prepared from fresh coconut milk without heating. A study of copra oil consumption by pregnant rats found no alteration in their hematologic and metabolic parameters [5]. In case of virgin coconut oil consumption, Famurewa et al. [6] found a reduction in total cholesterol, triglycerides and low-density lipoprotein with an increased level of high-density lipoprotein in normal young male rats, whereas Alves et al. [7] found a reduction of oxidative stress in the aortic blood vessels of spontaneously hypertensive rats. In studies on the human consumption of virgin coconut oil, Voon et al. [8] found no alteration in the thrombogenicity indices: cellular adhesion molecules, thromboxane $\mathrm{B}_{2}\left(\mathrm{TXB}_{2}\right)$ and the $\mathrm{TXB}_{2} /$ protacyclin ratio in healthy Malaysian adults. Similarly, Valente et al. [9] found no change in energy metabolism and cardiometabolic risk markers in women with excess body fat after the acute consumption of an isocaloric mixed breakfast containing $25 \mathrm{ml}$ of virgin coconut oil compared to a control group, but the breakfast promoted less appetitive response. However, Cardoso et al. [10] found that a virgin coconut oil-rich diet caused increases in HDL cholesterol and a decreased waist circumference and body mass in coronary artery disease patients. 
For coconut milk consumption, our group recently demonstrated that the consumption of pure dried fresh coconut milk for 6 weeks by middle-aged male rats caused an up-regulation of blood vessel endothelial nitric oxide synthase (eNOS) and cystathionine- $\gamma$-lyase (CSE) enzyme protein expression. This resulted in an attenuated contractile response to phenylephrine and potentiated relaxation to acetylcholine on the rats' thoracic aortic rings, with a decreased fasting plasma glucose level [11]. The present study aimed to investigate whether the oil from the coconut milk is responsible for those effects. The study has been performed using middle-aged rats (age 12-14 month) as this is the stage associated with endothelial dysfunction and a consequent decrease in $\mathrm{NO} / \mathrm{H}_{2} \mathrm{~S}$ production [12-13]. It is also the stage for early pathological changes in the development of cardiovascular disease [14-16]. The results have provided new information relating not only to classical risk factors such as blood pressure and the plasma lipid profile, but also to body fat accumulation and vascular function following virgin coconut oil consumption especially in middle-aged rats.

\section{METHODS}

\section{Coconut-milk oil preparation}

Fresh mature coconut (11-12 month) kernel was grated and compressed using an electric screw press to obtain a large sample of fresh aqueous coconut milk. The milk was then filtered through a cloth filter followed by lyophilization to obtain fresh dried coconut milk, which was kept at -20 ${ }^{\circ} \mathrm{C}$ until use.

The dried coconut milk was centrifuged $(3,200 \mathrm{rpm})$ at room temperature to achieve pure virgin coconut milk oil (CO) with a yield of $70 \%$ dried coconut milk and kept at $-20{ }^{\circ} \mathrm{C}$ until use.

The CO was analyzed for its fatty acid composition by LC-MS at the Central Equipment Center, Kasetart University, and analysed for its cholesterol and $\alpha$-tocopherol (vitamin E) concentrations by in-house method TE-CH-143 based on AOAC (2016) 976.26 at the Central Laboratory (Thailand) Co., Ltd.

\section{Pharmacological studies}

Middle-aged (12-14-month-old) Wistar male rats were bought from the National Laboratory Animal Center, Mahidol University. The animals were housed in controlled environmental conditions at $25^{\circ} \mathrm{C}$ on a $12 \mathrm{~h}$ dark and $12 \mathrm{~h}$ light cycle and allowed access to standard food (Perfect Companion Group Co. Ltd, Thailand) and tap water ad libitum. The animal methods employed in this study were approved by the Prince of Songkla University Animal Ethics Committee (Ethic Number: Ref. 06/57). The investigation conformed to the Guide for the Care and Use of Laboratory Animals (CIOMS Guidelines). The rats were randomly allocated to three groups with six animals in each group using sample size calculation formula for comparison between two group, sample size $=2 \mathrm{SD}^{2}\left(Z^{\alpha / 2}+Z^{\beta}\right)^{2} / d^{2}[17]$. The experimental group was treated by oral administration of 1 or $3 \mathrm{ml} / \mathrm{kg} \mathrm{CO}$ (corresponding to the amount of oil used to prepare one or three servings of Thai fast food, respectively), or distilled water, once a day for 6 weeks. The body weight and $24 \mathrm{~h}$ food intake was recorded one day before receiving oral gavage of each oil ration or distilled water (i.e., day 0 ) and again every $7^{\text {th }}$ day over the 6 -week period.

\section{Effects of the CO treatment on the basal blood pressure and on the haematology and clinical biochemical analysis}

The same methods as previously described [18] were used for haematology and clinical biochemical analysis. At the end of the 6-week $\mathrm{CO}$ or distilled water (DW) treatment, each rat was 
anaesthetized with thiopental sodium $(60 \mathrm{mg} / \mathrm{kg})$ after fasting for $13-15 \mathrm{~h}$. Their basal systolic and diastolic blood pressure and heart rate were recorded via the right common carotid artery by a polyethylene catheter connected to a polygraph. The data were collected after a $40 \mathrm{~min}$ equilibration period.

After measuring the basal blood pressure and heart rate, the rat was sacrificed by decapitation with a guillotine and two blood samples were collected in test tubes. The first was analyzed for glucose and lipid levels by enzymatic methods using an automatic chemistry analyzer routinely operated at Prince of Songkla University Hospital. The other was sent to a hematology laboratory and subjected to a total blood count procedure measured by an automated hematology analyzer.

\section{Effects of CO or DW treatment on internal organs and lipid accumulation}

The decapitated rat was dissected as previously described [18]. The heart, lungs, liver, adrenal glands, kidneys, testes, visceral fats from the epididymis, and testis, retroperitoneal and subcutaneous fats were removed and weighed .

Two pieces of liver (middle lobe) were cut, embedded into a cryostat gel, the sections (20 $\mu \mathrm{m}$ thick) were stained with oil red $\mathrm{O}(0.5 \%$ in absolute propylene glycol $)$, and mounted with glycerine jelly for observation by light microscopy. The aortic arch was collected and was cleared of adhering fat and connective tissue before being stained with oil red-O using the same method as for the liver tissue. The oil red $\mathrm{O}$ on each slide of the liver tissue and of the aortic arch was extracted

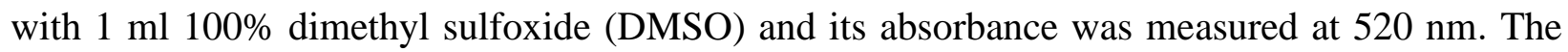
concentration of the oil red $\mathrm{O}$ was obtained from the standard curve of known concentrations of oil red $\mathrm{O}$ in $100 \%$ DMSO $(\mu \mathrm{g} / \mathrm{ml})$. The area of a thin section of the whole liver and of the aortic arch was measured using the Auto CAD 2005 program. The accumulated lipid in the liver tissue and at the aortic arch was expressed in terms of $\mu \mathrm{g} / \mathrm{ml} / \mathrm{cm}^{2}$ of the liver tissue thin section area and the aortic arch, respectively.

\section{Preparation of the thoracic aortic rings}

The thoracic aorta was removed from the decapitated rat and placed in oxygenated $37{ }^{\circ} \mathrm{C} \mathrm{Krebs-}$ Henseleit solution, and the adhering connective tissue was removed. Six adjacent rings of 4-5 mm in length were cut. For one ring the endothelium layer was removed with a small cotton bud. Each aortic ring was mounted with two stainless steel hooks in a $20 \mathrm{ml}$ organ bath containing KrebsHenseleit solution of the following composition (mM): $\mathrm{NaCl} 118.3, \mathrm{KCl} 4.7, \mathrm{CaCl}_{2} 1.9, \mathrm{MgSO}_{4}$ 7, $\mathrm{H}_{2} \mathrm{O}$ 0.45, $\mathrm{KH}_{2} \mathrm{PO}_{4}$ 1.18, $\mathrm{NaHCO}_{3}$ 25.0, glucose 11.66, $\mathrm{Na}_{2}$ EDTA 0.024 and ascorbic acid 0.09, maintained at $37{ }^{\circ} \mathrm{C}$ and bubbled with carbogen $\left(95 \% \mathrm{O}_{2}\right.$ and $5 \% \mathrm{CO}_{2}$ gas mixture). One of the hooks was fixed at the bottom and the other was connected to a transducer for recording the isometric tension with a polygraph. The tissues were equilibrated for $60 \mathrm{~min}$ under a resting tension of $1 \mathrm{~g}$ and the bath solution was replaced with pre-warmed oxygenated Krebs-Henseleit solution every $15 \mathrm{~min}$.

At the end of the equilibration period, each aortic ring was tested for the viability of the endothelium by precontraction with phenylephrine $(3 \mu \mathrm{M})$ until the response reached a plateau $(5-$ $8 \mathrm{~min})$, and then the addition of acetylcholine $(30 \mu \mathrm{M})$. Endothelial viability was judged by a > $65 \%$ vasorelaxation back to the tension generated by the ring before adding the phenylephrine. Denudation was confirmed by the absence of vasorelaxation following the response to the addition 
of acetylcholine. The preparations were then washed several times with Krebs-Henseleit solution and allowed to fully relax for $45 \mathrm{~min}$ before the experimental protocol began.

\section{Effects of the CO or DW treatment on the pharmacological vascular functions}

\section{Role of nitric oxide}

At the end of the 45-min re-equilibration period after the functional endothelium testing, the basal tension of the thoracic aortic rings with intact endothelium and the rings without endothelium was adjusted to the optimal tension of $2 \mathrm{~g}$ and equilibrated for another $10 \mathrm{~min}$, and the contractile response to a cumulative concentration-response $(C-R)$ curve of phenylephrine was then obtained. This was followed by several washings, and the aortic ring was allowed to fully relax for $50 \mathrm{~min}$. Then the endothelium-intact aortic rings were pre-incubated with N-nitro-L-arginine (L-NA) for $40 \mathrm{~min}$, and then a second $C$ - $R$ curve to phenylephrine was obtained.

Using another set of endothelium-intact thoracic aortic rings, each ring was equilibrated under a basal tension of $2 \mathrm{~g}$ for $10 \mathrm{~min}$ and was then precontracted with phenylephrine $(3 \mu \mathrm{M})$ for $10-15$ min followed by the determination of the cumulative dilator $C-R$ curves to acetylcholine.

\section{Role of $\mathrm{H}_{2} \mathrm{~S}$}

After equilibration, the endothelium-denuded thoracic aortic rings were incubated with L-NA for 40 min under a basal tension of $3 \mathrm{~g}$. Then a cumulative $C-R$ curve to phenylephrine was obtained in the presence of L-NA, followed by several washings and re-equilibration for $60 \mathrm{~min}$ in the presence of L-NA to allow full relaxation of the blood vessels to their original baseline of $3 \mathrm{~g}$. After that, PAG was added to the incubation and left for 10-15 min until the aortic contraction reached a plateau, and a further cumulative $C-R$ curve to phenylephrine was obtained in the presence of L-NA and PAG .

\section{eNOS and CSE Western blot analysis}

The thoracic aortae of the CO-treated groups and the distilled water control groups $(n=4)$ were obtained in order to measure the expression level of the enzymes, eNOS and CSE. After removal of the adhering connective tissue, the blood vessel was then cut into small rings and the endothelium removed with a small cotton bud. The rings were then kept at $-70{ }^{\circ} \mathrm{C}$ until use. Protein extraction from the tissues and Western blot analysis were carried out as previously described. Briefly, the total proteins extracted from the homogenized tissue of each animal in lysis RIPA buffer (25 mM Tris-HCl, pH 7.6), $150 \mathrm{mM} \mathrm{NaCl,} \mathrm{1 \%} \mathrm{NP-40,} \mathrm{1 \%} \mathrm{sodium} \mathrm{deoxycholate,} \mathrm{0.1 \%}$ SDS, $0.5 \mathrm{mM}$ EDTA containing a GE Healthcare protease inhibitor cocktail. The protein lysate of each animal was centrifuged and the supernatant used to quantify the protein content by Bradford assay. Protein at $50 \mu \mathrm{g}$ was run on $12 \%$ SDS-polyacrylamide gel electrophoresis. Then, the protein bands were transferred onto nitrocellulose membranes. The membranes were blocked with 5\% low fat dry milk in Tris buffer saline- $0.1 \%$ Tween 20 (TBS-T) for $1 \mathrm{~h}$, followed by primary antibody incubation against eNOS $(1: 250)$, CSE $(1: 1,000)$ and $\beta$-actin $(1: 1,000)$ dissolved in $1 \%$ low fat dry milk in TBS-T overnight at $4^{\circ} \mathrm{C}$ (the rabbit eNOS and rabbit $\beta$-actin antibodies used were from Cell Signalling Technology, USA, and the mouse CSE was from Abnova, USA). The membranes were then incubated with HRP-conjugated rabbit $\operatorname{IgG}(1: 5,000)$ for eNOS and $\beta$-actin and mouse IgG antibody $(1: 5,000)$ for CSE. The membranes were incubated with a chemiluminesescence 
detection kit (Pierce, Rockford, USA) and the protein signal was detected by Fusion FX5XT spectra/ Superbright (Vilber Lourmat).

\section{Drugs}

The following drugs were used: Acetylcholine chloride, $\mathrm{N}^{\mathrm{G}}$-nitro-L-arginine (L-NA), norepinephrine, phenylephrine hydrochloride, DL-propagylglycine (PAG), pentobarbital, and oil red O from Sigma, USA. Glyceryl trinitrate was obtained from Mycomed, Denmark. Acetylcholine chloride and phenylephrine were dissolved in a solution containing $\mathrm{NaCl} 19 \mathrm{~g} / \mathrm{l}$, $\mathrm{NaH}_{2} \mathrm{PO}_{4} 0.19 \mathrm{~g} / \mathrm{l}$ and ascorbic acid $0.03 \mathrm{~g} / \mathrm{l}$.

\section{Statistical analysis}

The results were expressed as the mean \pm standard error of the mean (SEM) $(n=6$ for vascular function study and $n=4$ for Western blotting, where $n$ is the number of animals). Maximal contractile response and EC50 values were calculated for vascular reactivity experiments using GraphPad Prism V.5.00. Statistical differences were determined by $t$-test or by one-way analysis of variance (ANOVA), followed by Tukey's range test using GraphPad Prism V.5.0. A $p$ value < 0.05 was considered to indicate a significant difference between values.

\section{RESULTS}

\section{Fatty acid composition of the $\mathrm{CO}$}

The main component of the fatty acid composition of the $\mathrm{CO}$ was similar to that previously reported [11]: lauric acid (40\%) followed by myristic acid (17\%), palmitic acid (8\%), linoleic acid ( $\omega$-6-unsaturated fatty acid, 5\%), capric acid (4\%), stearic acid (3\%) and caprelic acid and linoleic acid ( $\omega$-3-unsaturated fatty acid, 1\%). The cholesterol and $\alpha$-tocopherol content were 0 (not detectable) and $0.09 \mathrm{mg} / 100 \mathrm{~g}$, respectively (Table 1).

Table 1. Fatty acids (in percent), and cholesterol and vitamin E ( $\alpha$-tocopherol) (mg/ $100 \mathrm{~g}$ ) composition of the coconut oil (CO).

\begin{tabular}{lcc}
\hline \multicolumn{1}{l}{ Fatty acid name } & \% in CCM oil \\
\hline Caprylic acid & $(\mathrm{C} 8: 0), \mathrm{MCF}$ & $1.05 \pm 0.00$ \\
Capric acid & $(\mathrm{C} 10: 0), \mathrm{MCF}$ & $3.55 \pm 0.00$ \\
Lauric acid & $(\mathrm{C} 12: 0), \mathrm{MCF}$ & $40.68 \pm 0.08$ \\
Myristic acid & $(\mathrm{C} 14: 0), \mathrm{LCF}$ & $17.53 \pm 0.02$ \\
Palmitic acid & $(\mathrm{C} 16: 0), \mathrm{LCF}$ & $7.89 \pm 0.00$ \\
Stearic acid & $(\mathrm{C} 18: 0), \mathrm{LCF}$ & $2.87 \pm 0.00$ \\
Oleic acid $\quad(\mathrm{C} 18: 1), \mathrm{LCF}$ & $4.65 \pm 0.00$ \\
Linoleic acid & $(\mathrm{C} 18: 2), \mathrm{LCF}$ & $1.01 \pm 0.00$ \\
Cholesterol & & No detectable \\
Vitamin E $(\alpha$-tocopherol $)$ & $0.09 \mathrm{mg} / 100 \mathrm{~g}$ \\
\hline
\end{tabular}


Effects of $\mathrm{CO}$ treatment on the body weight, food intake, internal organs, adipose tissue and blood chemistry

In comparison to the DW control group, there was no difference in animal body weight, food intake (Figure 1), complete blood cell count or the internal organ weights (supplementary Table 1-2) after treatment with 1 or $3 \mathrm{ml} / \mathrm{kg}$ CO. Both $1 \mathrm{ml} / \mathrm{kg}$ and $3 \mathrm{ml} / \mathrm{kg}$ CO caused an increase in retroperitoneal fat accumulation (Table 2), whereas $3 \mathrm{ml} / \mathrm{kg}$ but not $1 \mathrm{ml} / \mathrm{kg} \mathrm{CO}$ caused a decrease in liver cell lipid accumulation (Figure 2) but there was no significant difference in the lipid accumulation for the internal wall of the aortic arch (Figure 3). At $3 \mathrm{ml} / \mathrm{kg}$ but not at $1 \mathrm{ml} / \mathrm{kg}, \mathrm{CO}$ treatment caused lower plasma levels of alkaline phosphatase, blood urea nitrogen, and glucose compared to that of the DW-treated group (Table 3-4).

\section{Effects of CO treatment on blood pressure}

$\mathrm{CO}$ treatment did not affect the basal arterial blood pressure and heart rate of the anesthetized middle-aged rats when compared to that of the DW control group (supplementary Table 3).
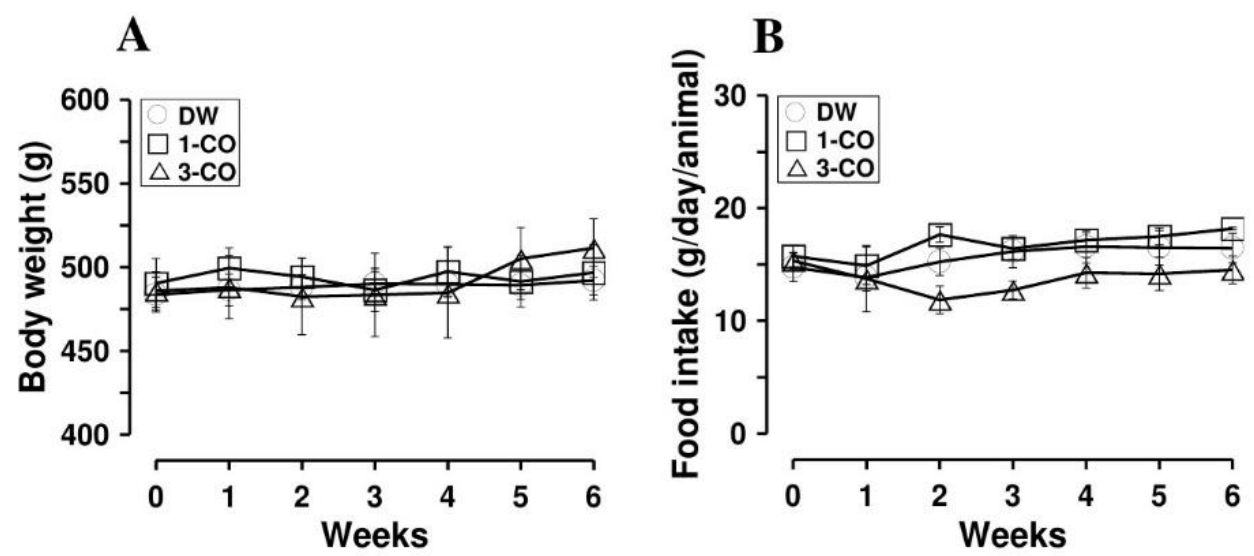

Figure 1. Effects of CO- (1 or $3 \mathrm{ml} / \mathrm{kg}$ ) or distilled water (DW) consumption by the middle-aged male rats on body weight (left) and food intake (right). Each point represents mean \pm SEM of 6 rats.

Table 2. Effects of 6 weeks coconut oil (CO) consumption ( 1 or $3 \mathrm{ml} / \mathrm{kg}$ ) on body adipose tissue accumulation in middle-aged rats.

Adipose tissue weight/ $100 \mathrm{~g}$ body weight (\% g)

\begin{tabular}{llllll} 
Treatments & \multicolumn{1}{c}{ Epididymis } & Prostate & Mesentery & Retroperitoneal & Subcutaneous \\
\cline { 2 - 6 } DW & $2.01 \pm 0.25$ & $0.09 \pm 0.02$ & $2.05 \pm 0.22$ & $2.20 \pm 0.39$ & $6.71 \pm 0.73$ \\
CO 1 ml/kg & $2.56 \pm 0.34$ & $0.14 \pm 0.02$ & $2.13 \pm 0.02$ & $3.11 \pm 0.49^{\mathrm{a}}$ & $7.01 \pm 0.78$ \\
& $(p=.21)$ & $(p=.11)$ & $(p=.66)$ & $(p=.04)$ & $(p=.78)$ \\
CO 3 ml/kg & $2.72 \pm 0.30$ & $0.15 \pm 0.03$ & $2.22 \pm 0.03$ & $3.47 \pm 0.34^{\mathrm{a}}$ & $7.96 \pm 0.96$ \\
& $(p=.09)$ & $(p=.06)$ & $(p=.36)$ & $(p=.04)$ & $(p=.31)$ \\
\hline
\end{tabular}

${ }^{a}$ significantly higher than control group, $p<0.05$. 
A

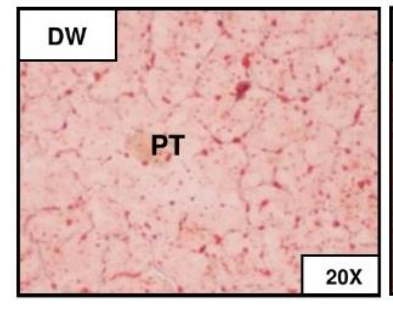

B

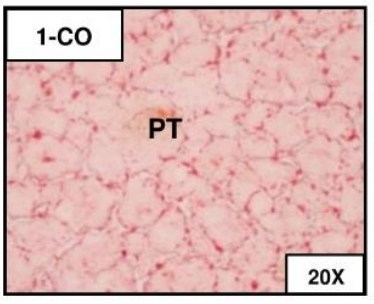

C

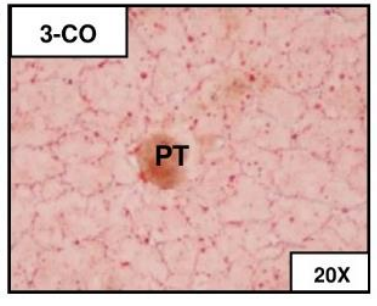

D

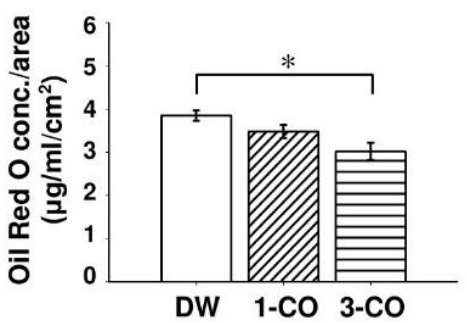

Figure 2. Effects of CO- (1 or $3 \mathrm{ml} / \mathrm{kg}$ ) or distilled water (DW) consumption by the middle-aged male rats on liver cell lipid accumulation. (A) distilled water (DW), (B) CO $1 \mathrm{ml} / \mathrm{kg}$, (C) CO $3 \mathrm{ml} / \mathrm{kg}$ and (D) oil red $\mathrm{O}$ concentration. Values represent mean \pm SEM of 6 experiments.

*significantly lower than that of the distilled water control group, $p<0.05$.

(PT = Portal triad; oil red O staining of liver tissue frozen section, $20 \mathrm{~mm}$ thick, 20X magnification).
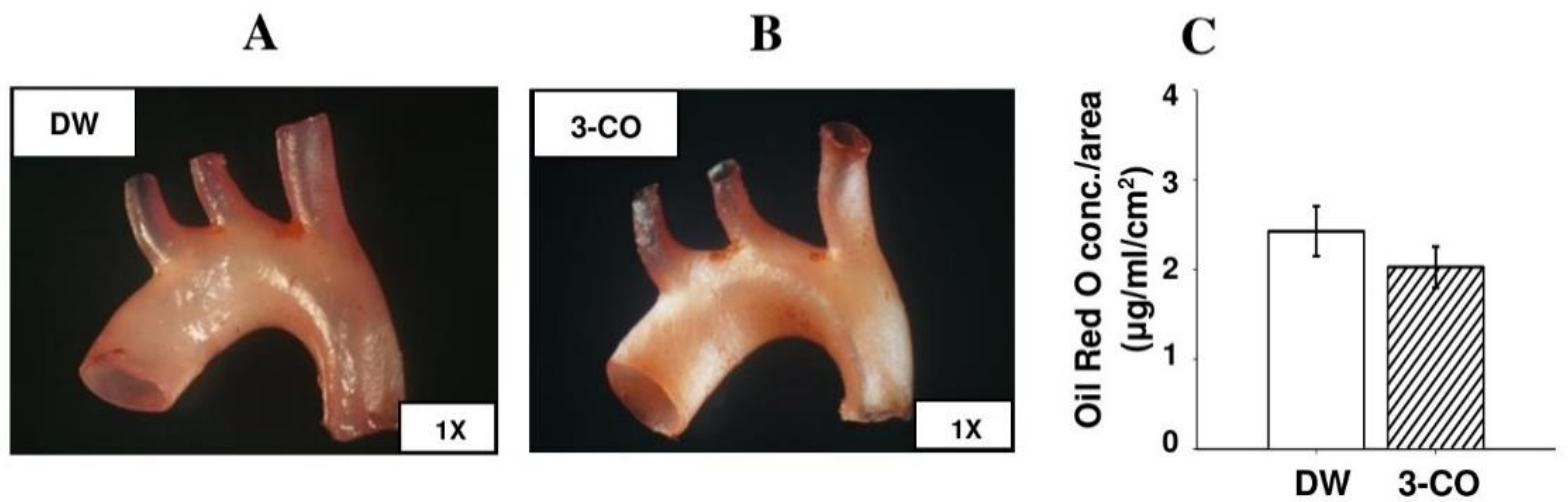

Figure 3. Effects of $\mathrm{CO} 3 \mathrm{ml} / \mathrm{kg}$ or distilled water (DW) consumption by the middle-aged male rats on lipid accumulation at the aortic arch. (A) distilled water (DW), (B) $\mathrm{CO} 3 \mathrm{ml} / \mathrm{kg}$ and (C) oil red O concentration. Values represent mean \pm SEM of 6 experiments.

Table 3. Effects of 6 weeks coconut oil (CO) consumption ( 1 or $3 \mathrm{ml} / \mathrm{kg}$ ) on liver and kidney enzymes in middle-aged rats.

\begin{tabular}{llll}
\hline NLAC-MU- & ALP $(\mathbf{U} / \mathrm{L})$ & BUN $(\mathbf{m g} \%)$ & CREAT $(\mathbf{m g} \%)$ \\
normal range & $\mathbf{4 6 . 0 0 - 9 2 . 0 0}$ & $\mathbf{1 0 . 3 0 - 2 3 . 6 0}$ & $\mathbf{0 . 5 4 - 0 . 6 9}$ \\
\hline DW & $85.7 \pm 4.2$ & $21.8 \pm 0.6$ & $0.4 \pm 0.01$ \\
CO $\mathbf{~} \mathbf{~ m l} / \mathbf{k g}$ & $95.0 \pm 9.4$ & $21.4 \pm 0.9$ & $0.5 \pm 0.03$ \\
& $(p=.36)$ & $(p=.71)$ & $(p=.08)$ \\
CO 3 $\mathbf{~ m l} / \mathbf{k g}$ & $68.5 \pm 3.4^{\mathrm{a}}$ & $18.5 \pm 1.1^{\mathrm{a}}$ & $0.4 \pm 0.02$ \\
& $(p=.01)$ & $(p=.02)$ & $(p=.09)$
\end{tabular}

${ }^{\mathrm{a}}$ significantly lower than control group, $p<0.05$. 
Table 4. Effects of 6 weeks coconut oil (CO) consumption (1 or $3 \mathrm{ml} / \mathrm{kg}$ ) on fasting blood glucose and lipid profile in middle-aged male rats.

\begin{tabular}{|c|c|c|c|c|c|c|}
\hline NLAC- MU- & Glucose & Triglyceride & Cholesterol & HDL-C & LDL-C & LDL/HDL \\
\hline $\begin{array}{l}\text { Normal range } \\
(\mathrm{mg} \%)\end{array}$ & $122.1-180.8$ & $61.0-164.0$ & $46.0-98.0$ & - & - & - \\
\hline DW & $135.0 \pm 8.1$ & $73.4 \pm 8.6$ & $76.7 \pm 5.6$ & $61.5 \pm 4.9$ & $\begin{array}{c}12.1 \pm \\
1.4\end{array}$ & $0.2 \pm 0.01$ \\
\hline \multirow[t]{2}{*}{ CO $1 \mathrm{ml} / \mathrm{kg}$} & $140.9 \pm 9.9$ & $66.7 \pm 5.5$ & $70.3 \pm 3.8$ & $49.8 \pm 2.7$ & $\begin{array}{c}11.1 \pm \\
1.6\end{array}$ & $0.2 \pm 0.02$ \\
\hline & $(p=.65)$ & $(p=.54)$ & $(p=.38)$ & $(p=.07)$ & $(p=.61)$ & $(p=.34)$ \\
\hline \multirow[t]{2}{*}{ CO $3 \mathrm{ml} / \mathrm{kg}$} & $102.5 \pm 7.5^{\mathrm{a}}$ & $84.9 \pm 19.9$ & $84.7 \pm 7.9$ & $60.5 \pm 4.1$ & $\begin{array}{c}15.6 \pm \\
1.4\end{array}$ & $0.3 \pm 0.02$ \\
\hline & $(p=.01)$ & $(p=.39)$ & $(p=.42)$ & $(p=.88)$ & $(p=.11)$ & $(p=.15)$ \\
\hline
\end{tabular}

${ }^{a}$ significantly lower than control group, $p<0.05$.

\section{Effects of CO treatment on vascular functions}

\section{Effect on contraction and relaxation of the thoracic aorta}

CO-treatment caused decreased maximal contractile responses with no changes in $\mathrm{EC}_{50}$ to phenylephrine of the endothelium-intact thoracic aortic rings in comparison to the DW control group (Figure 4A and Table 5). The effect disappeared in the presence of L-NA or the removal of the vascular endothelium (Figure 4B-C). The addition of PAG into the incubation medium caused a spontaneous contraction of the endothelium-denuded thoracic aortic rings in the presence of LNA for all groups, DW $(0.63 \pm 0.11 \mathrm{~g}), 1 \mathrm{ml} / \mathrm{kg} \mathrm{CO}(0.78 \pm 0.22 \mathrm{~g})$ and $3 \mathrm{ml} / \mathrm{kg} \mathrm{CO}(1.39 \pm 0.56$ g). However, the $3 \mathrm{ml} / \mathrm{kg}$ CO-treated group caused about 2 -fold increased spontaneous contraction of the aortic rings compared to that of the DW- or $1 \mathrm{ml} / \mathrm{kg}$ CO-treated groups. This effect subsequently resulted in a greater contraction of the phenylephrine $C-R$ curves of the thoracic aortic rings obtained from the $3 \mathrm{ml} / \mathrm{kg} \mathrm{CO}$-treated rats than that of the other groups (Figure 4D).

The relative relaxation to acetylcholine of the endothelium-intact aortic rings pre-contracted with phenylephrine obtained from the $3 \mathrm{ml} / \mathrm{kg}$ (but not the $1 \mathrm{ml} / \mathrm{kg}$ CO-treated rats) was higher than that of the DW control group (Figure 5A and Table 6). However, the relaxation to glyceryl trinitrate of the endothelium-intact tissue in the presence of L-NA of the CO-treated ( $1 \mathrm{or} 3 \mathrm{ml} / \mathrm{kg}$ ) groups were not different from the DW control group (Figure 5B).

\section{eNOS and CSE Western blot analysis}

The quantitative expression of the vascular eNOS and CSE protein expression of the CO-treated rats was significantly higher than that of the DW control group (Figure 6). 
A

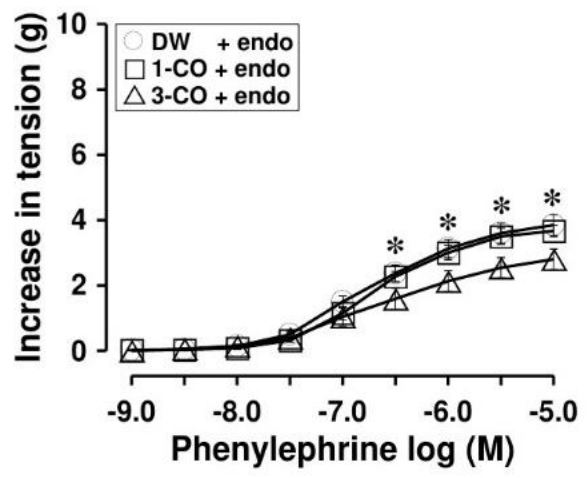

C

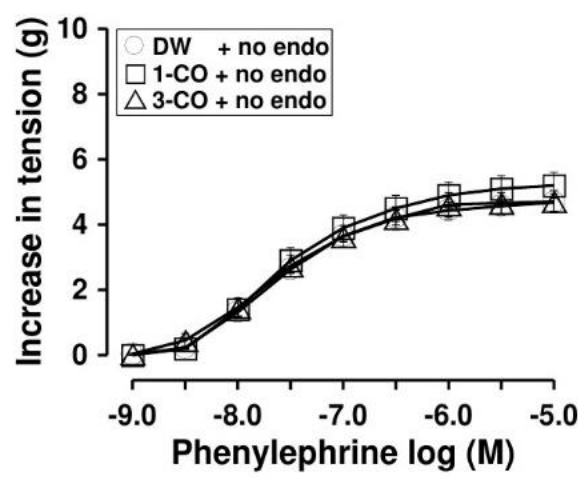

B
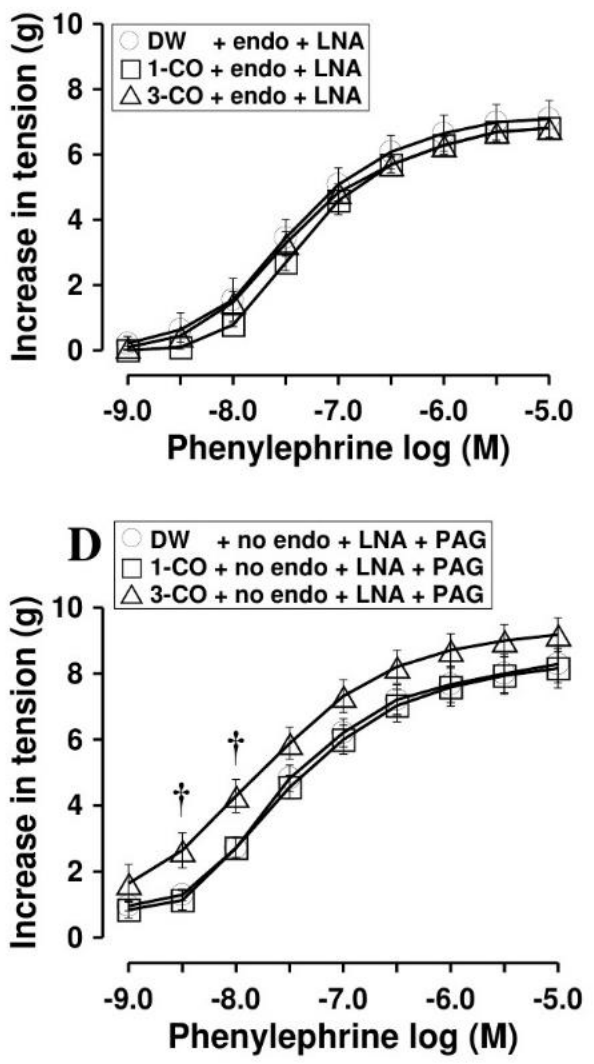

Figure 4. Effects of 6 weeks oral administration of CO- (1 or $3 \mathrm{ml} / \mathrm{kg}$ ) or distilled water (DW, control) by middle-aged male rats on contractile response to phenylephrine of endothelium-intact (endo, a), endothelium-intact with L-NA (B), without endothelium (no endo, C), or without endothelium in the present of L-NA and PAG thoracic aorta (D). Values represent as mean \pm SEM; $n=6$. ${ }^{*}$ significantly lower than the control group and ${ }^{\dagger}$ significantly higher than the other groups, $p$ $<0.05$.

A

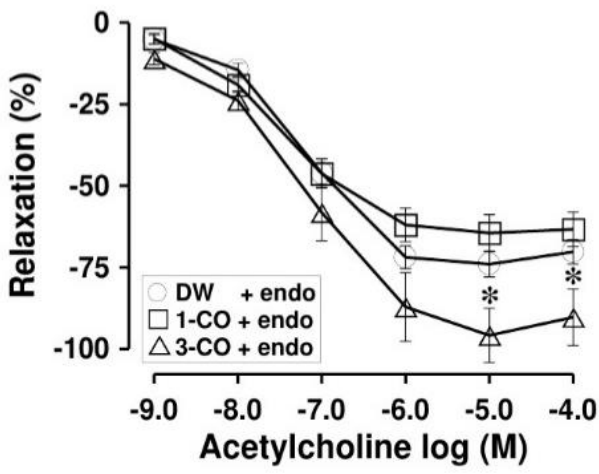

B

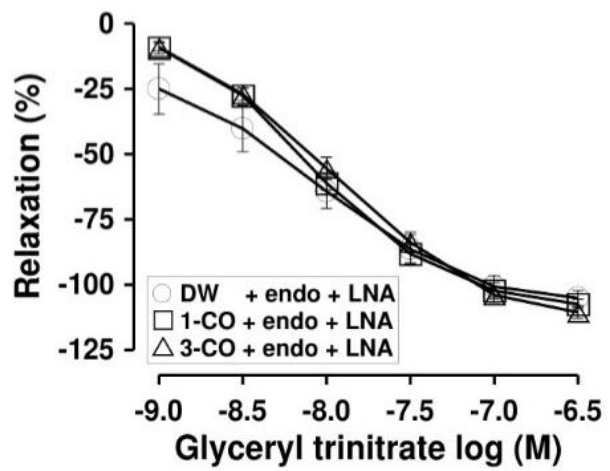

Figure 5. Effect of 6 weeks oral gavage of CO- (1 or $3 \mathrm{ml} / \mathrm{kg}$ ) or distilled water (DW, control) on relaxation of the endothelium-intact thoracic aortic ring precontracted with phenylephrine to acetylcholine (A) or to glyceryl trinitrate (GTN) in the presence of L-NA (B). Values represent as mean $\pm \mathrm{SEM} ; n=6$. ${ }^{*}$ significantly lower than the control group, $p<0.05$. 
A

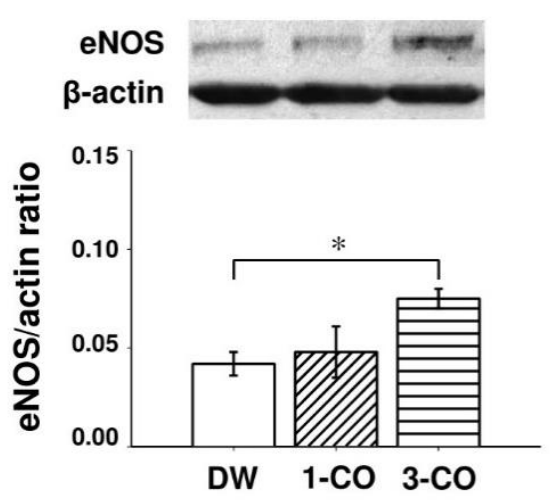

B

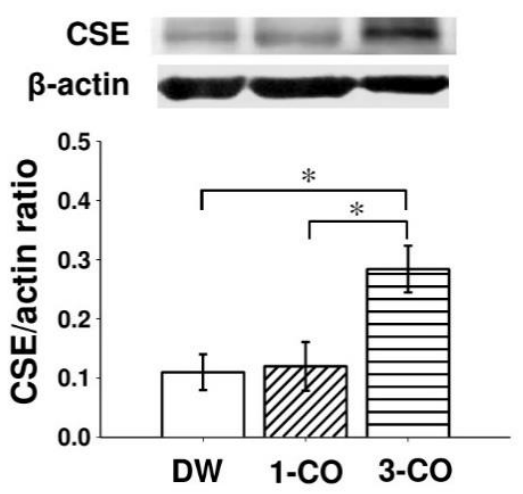

Figure 6. The effect of 6 weeks oral administration of CO- (1 or $3 \mathrm{ml} / \mathrm{kg}$ ), or distilled water (DW) on eNOS protein expression (A), or CSE protein expression (B) of the thoracic aorta. For each blot, $\beta$-actin expression is shown as a loading control. Values represent as mean $\pm \mathrm{SEM} ; n=4$. *significantly higher than that of the distilled water control group, $p<0.05$.

Table 5. $\mathrm{EC}_{50}$ and $\mathrm{E}_{\max }$ values of contractile responses to phenylephrine of the thoracic rings obtained from 1-3 ml/kg CO- or distilled water (DW) -treated middle-aged male rat.

\begin{tabular}{|c|c|c|c|c|c|c|}
\hline & \multicolumn{3}{|c|}{$\mathrm{EC}_{50}(\mathrm{nM}): 95 \%$ confidential limit } & \multicolumn{3}{|c|}{$\mathbf{E}_{\max }(\mathbf{g})$} \\
\hline & \multirow[t]{2}{*}{ DW } & \multicolumn{2}{|c|}{$\mathrm{CO}$} & \multirow[t]{2}{*}{ DW } & \multicolumn{2}{|c|}{$\mathrm{CO}$} \\
\hline & & $1 \mathrm{ml} / \mathrm{kg}$ & $3 \mathrm{ml} / \mathrm{kg}$ & & $1 \mathrm{ml} / \mathrm{kg}$ & $3 \mathrm{ml} / \mathrm{kg}$ \\
\hline Phenylephrine & & & & & & \\
\hline Endo & $\begin{array}{c}186.6 \\
(142.7-244.0)\end{array}$ & $\begin{array}{c}213.0 \\
(178.0-254.9)\end{array}$ & $\begin{array}{c}243.1 \\
(175.3-337.3)\end{array}$ & $3.9 \pm 0.3$ & $\begin{array}{l}3.7 \pm 0.2 \\
(p=.77)\end{array}$ & $\begin{array}{l}2.8 \pm 0.3^{\mathrm{a}} \\
(p=.03)\end{array}$ \\
\hline Endo+L-NA & $\begin{array}{c}34.4 \\
(28.3-41.7)\end{array}$ & $\begin{array}{c}46.2 \\
(35.9-59.4)\end{array}$ & $\begin{array}{c}42.5 \\
(34.5-53.0)\end{array}$ & $7.1 \pm 0.6$ & $\begin{array}{l}6.8 \pm 0.3^{b} \\
(p=.00)\end{array}$ & $\begin{array}{l}6.8 \pm 0.3^{\mathrm{b}} \\
(p=.00)\end{array}$ \\
\hline Endo + L-NA+PAG & $\begin{array}{c}78.3 \\
(62.1-98.7)\end{array}$ & $\begin{array}{c}58.0 \\
(45.3-74.1)\end{array}$ & $\begin{array}{c}46.8 \\
(38.5-56.9)\end{array}$ & $6.8 \pm 0.6$ & $\begin{array}{l}7.3 \pm 0.7^{\mathrm{b}} \\
(p=.00)\end{array}$ & $\begin{array}{l}7.6 \pm 0.2^{\mathrm{b}} \\
(p=.00)\end{array}$ \\
\hline No endo & $\begin{array}{c}21.7 \\
(17.0-27.7)\end{array}$ & $\begin{array}{c}22.0 \\
(14.9-32.5)\end{array}$ & $\begin{array}{c}19.7 \\
(15.8-24.7)\end{array}$ & $4.7 \pm 0.3$ & $\begin{array}{l}5.2 \pm 0.4^{\mathrm{b}} \\
(p=.00)\end{array}$ & $\begin{array}{c}4.7 \pm 0.3^{b} \\
(p=.00)\end{array}$ \\
\hline No endo+L-NA & $\begin{array}{c}16.4 \\
(8.6-31.5)\end{array}$ & $\begin{array}{c}27.8 \\
(17.3-44.8)\end{array}$ & $\begin{array}{c}18.9 \\
(12.1-29.5)\end{array}$ & $6.7 \pm 0.4$ & $\begin{array}{l}7.0 \pm 0.6^{\mathrm{b}} \\
(p=.00)\end{array}$ & $\begin{array}{l}6.9 \pm 0.4^{\mathrm{b}} \\
(p=.00)\end{array}$ \\
\hline $\begin{array}{l}\text { No endo+L-NA } \\
\text { + PAG }\end{array}$ & $\begin{array}{c}25.2 \\
(17.1-37.0)\end{array}$ & $\begin{array}{c}25.7 \\
(17.6-37.6)\end{array}$ & $\begin{array}{c}14.4 \\
(12.2-17.0)\end{array}$ & $8.3 \pm 0.6$ & $\begin{array}{l}8.2 \pm 0.6^{\mathrm{b}} \\
(p=.00)\end{array}$ & $\begin{array}{l}9.2 \pm 0.5^{b} \\
(p=.00)\end{array}$ \\
\hline
\end{tabular}

${ }^{a}$ significantly lower than the DW-treated and $1 \mathrm{ml} / \mathrm{kg}$ CO-treated group and ${ }^{\mathrm{b}}$ significantly higher than endothelium-intact group (Endo), $p<0.05$. 
Table 6. $\mathrm{EC}_{50}$ and $\mathrm{E}_{\max }$ values of vasodilatory responses to acetylcholine or glyceryl trinitrate of the thoracic rings precontracted with phenylephrine obtained from 1 or $3 \mathrm{ml} / \mathrm{kg} \mathrm{CO}$ - or distilled water (DW) -treated middle-aged male rat.

\begin{tabular}{|c|c|c|c|c|c|c|}
\hline & \multicolumn{3}{|c|}{$\mathrm{EC}_{50}(\mathrm{nM}): 95 \%$ confidential limit } & \multirow{3}{*}{ DW } & \multicolumn{2}{|c|}{$\mathbf{E}_{\max }(\mathbf{g})$} \\
\hline & \multirow[t]{2}{*}{ DW } & \multicolumn{2}{|c|}{$\mathrm{CO}$} & & \multicolumn{2}{|c|}{$\mathrm{CO}$} \\
\hline & & $1 \mathrm{ml} / \mathrm{kg}$ & $3 \mathrm{ml} / \mathrm{kg}$ & & $1 \mathrm{ml} / \mathrm{kg}$ & $3 \mathrm{ml} / \mathrm{kg}$ \\
\hline \multicolumn{7}{|l|}{ Acetylcholine } \\
\hline Endo+L-NA & $\begin{array}{c}64.5 \\
(25.1-165.4)\end{array}$ & $\begin{array}{c}32.7 \\
(18.9-56.7)\end{array}$ & $\begin{array}{c}67.2 \\
(23.6-191.4)\end{array}$ & $70.3 \pm 3.8$ & $\begin{array}{c}63.4 \pm 5.3 \\
(p=.35)\end{array}$ & $\begin{array}{c}90.3 \pm 8.7^{\mathrm{a}} \\
(p=.03)\end{array}$ \\
\hline \multicolumn{7}{|c|}{ Glyceryl trinitrate } \\
\hline Endo+L-NA & $\begin{array}{c}8.9 \\
(7.1-11.2)\end{array}$ & $\begin{array}{c}8.0 \\
(6.7-9.6)\end{array}$ & $\begin{array}{c}10.4 \\
(7.9-13.7)\end{array}$ & $105.1 \pm 2.8$ & $\begin{array}{c}107.4 \pm 1.8 \\
(p=.85)\end{array}$ & $\begin{array}{c}110.6 \pm 2.2 \\
(p=.34)\end{array}$ \\
\hline
\end{tabular}

${ }^{\mathrm{a}}$ significantly higher than the control group, $p<0.05$.

\section{DISCUSSION}

It has been previously demonstrated that coconut milk consumption at a dosage of $3 \mathrm{mg} / \mathrm{kg}$ but not $1 \mathrm{mg} / \mathrm{kg}$ produced some beneficial effects on the cardiovascular system in middle-aged male rats [11]. The present study thus investigated whether it is coconut oil which is responsible for such effects. To this end, dried fresh coconut milk was prepared as previously described, from which the oil (CO) fractions were isolated by centrifugation. Thus, the $\mathrm{CO}$ obtained used in this investigation was not heated. This is referred to as a virgin coconut oil type, the chemical composition being the same as in dried fresh coconut milk.

In the present study rats were treated at $\mathrm{CO}$ dosages of $1 \mathrm{ml} / \mathrm{kg}$ and $3 \mathrm{ml} / \mathrm{kg}$ which correspond to the amount of oil used to prepare one and three servings of Thai fast food. It was found that a dosage of $1 \mathrm{ml} / \mathrm{kg}$ of $\mathrm{CO}$ did not cause any change in the parameters studied except that the fat accumulation in the retroperitoneal tissue was increased. A dosage of $3 \mathrm{ml} / \mathrm{kg}$ of $\mathrm{CO}$ also caused increased retroperitoneal fat accumulation, but several beneficial effects on the cardiovascular system were found. Firstly, $\mathrm{CO}$ caused decreased fasting-plasma glucose and liver-cell lipid accumulation. These results were analogous to those reported by Naravanankutty et al. [19], and Zicker et al. [20] who found that virgin CO in the diet lowered the increase in blood glucose level and reduced hepatic damage and steatosis than the one with coconut oil in the diet of high-fructosefed rats and those with a high-refined carbohydrate-containing diet alone mice. Which might be due, respectively, to the high antioxidant efficacy and high content of medium chain fatty acid of the virgin coconut oil diet. Secondly, it caused a slight decrease in the plasma alkaline phosphatase (ALP) and blood urea nitrogen (BUN) levels which indicated that CO consumption at this dosage did not harm the liver and kidney functions. As it is well known that if there is a cholestasis or bile duct ligation, it would increase plasma ALP level [21-24], as well as chronic kidney disease would increase BUN level [25-27]. Thirdly, although CO treatment did not affect the basal blood pressure 
and heart rate, it caused a decreased maximal contractile response to phenylephrine in the thoracic aortic rings compared to that of the DW control group. The effect was abolished by L-NA or the removal of the vascular endothelium. In addition, the vasodilatation to acetylcholine of the aortic ring precontracted with phenylephrine in the $\mathrm{CO}$-treated rats was significantly higher than that of the DW control group, which suggested that $\mathrm{CO}$ treatment might cause increased NO production from the vascular endothelium. This was confirmed by the finding that aortic blood vessel eNOS enzyme expression in the $\mathrm{CO}$ treated groups was significantly greater than that of the DW control group. However, the increased NO availability might also be modified by other factors such as: post-translational regulation of eNOS activity, the availability of eNOS substrate and cofactors, or level of endogenous NOS inhibitors or oxidative stress, of which parameters are needed for further extensive studies.

In our previous publication, it was also found that coconut milk consumption caused increased blood vessel $\mathrm{H}_{2} \mathrm{~S}$ production [11]. Thus, the present study investigated whether $\mathrm{CO}$ consumption would affect $\mathrm{H}_{2} \mathrm{~S}$ production by studying the $C-R$ curve to phenylephrine in the presence of PAG after the aortic ring had been incubated with L-NA, in order to prevent any disturbance by the NO. It was found that PAG caused increased vascular responsiveness to phenylephrine compared to the DW control group in the $3 \mathrm{ml} / \mathrm{kg}$ CO-treated group but not in the $1 \mathrm{ml} / \mathrm{kg} \mathrm{CO}$-treated group. This result suggests that $\mathrm{CO}$ might cause increased blood vessel $\mathrm{H}_{2} \mathrm{~S}$ production, and the finding of greater blood vessel CSE enzyme expression for the CO treated group than that of the DW control group confirmed this finding. These results are similar to those of the finding related to coconut milk consumption. However, both dosages of CO (1 and $3 \mathrm{ml} / \mathrm{kg})$ caused increased retroperitoneal fat accumulation, whereas dried fresh coconut milk-treatment did not affect body lipid accumulation, suggesting that some other bioactive components besides the $\mathrm{CO}$ of the dried fresh coconut milk antagonizes the accumulation of $\mathrm{CO}$ in the body fat. As coconut milk composition are not only lipids (coconut oil, 41.5\%), but with a small amount of carbohydrates (5.2\%) and proteins (4.5\%) [3]. Thus, further experiments to isolate and study the activities of the crude coconut protein and/or crude carbohydrates/sugars from the precipitate left over from the coconut milk oil separation of the dried fresh coconut milk, would be needed to clarify this possibility.

\section{CONCLUSIONS}

The study suggests that the consumption of $\mathrm{CO}$ at $1 \mathrm{ml} / \mathrm{kg}$ did not have any effect on the cardiovascular system except for the increase in retroperitoneal fat accumulation. When the consumption was increased to $3 \mathrm{ml} / \mathrm{kg}$, it caused both beneficial and harmful effects by decreasing the fasting serum glucose and liver lipid accumulation and an increase in blood vessel eNOS and CSE protein expression, which resulted in an increase in $\mathrm{NO}$ and $\mathrm{H}_{2} \mathrm{~S}$ production, which, in turn, attenuated vasoconstriction to phenylephrine and facilitated relaxation to acetylcholine. However, the increase in retroperitoneal fat accumulation is a negative indicator for metabolic syndrome development which is a matter of concern for the long-term consumption of $\mathrm{CO}$ and the consumption of CO should thus be limited. Nevertheless, to date, this is the first report of the use of appropriate methods to provide good evidence that $\mathrm{CO}$ also produces beneficial cardiovascular effects in middle-aged male rats. 
List of Abbreviations: endothelial nitric oxide synthase (eNOS), cystathionine- $\gamma$-lyase (CSE), coconut milk oil (CO), N-nitro-L-arginine (L-NA), DL-propargylglycine (PAG)

Competing interests: The study was supported by the Thailand Research Fund, Thailand (the grant No. RSA 5980045). The authors declared no conflict of interest.

Authors'contributions: CJ designed, conducted the research and wrote the manuscript. JN and PC conducted the research and performed statistical analysis. KK assisted for western blot technique and NR assisted for oil red O staining technique. All authors read and approved the final version of the manuscript.

Acknowledgments: This work was supported by the Thailand Research Fund, Thailand. The authors thank Miss. Srisurat Duangsai for her technical assistance and Prof. Michael J. Mulvany, Aarhus University, Denmark, for his valuable comments and editing the manuscript.

\section{REFERENCES}

1. Gwee CN: New technologies open the passage into new usage of coconut milk products. In: Maneepun S, Varangoon P, Phitakpol B (editors). Food Science and Technology in Industrial Development. Bangkok: Institute of Food Research and Product Development, Kasetsart University. 1988;157-162.

2. D'Amato A, Fasoli E, Righetti PG: Harry belafonte and the secret proteome of coconut milk. J Proteomics. 2012; 75:914-920.

3. Pehowich DJ, Gomes AV, Barnes JA: Fatty acid composition and possible health effects of coconut constituents. West Indian Med J. 2000; 49:128-133.

4. DebMandal M, Mandal S: Coconut (Cocos nucifera L.: Arecaceae): in health promotion and disease prevention. Asian Pac J Trop Med. 2011; 4:241-247.

5. Nandakumaran M, Angelaki E, Al-Azemi N, Al-Sarraf H, Al-Saleh E: Influence of coconut oil administration on some hematologic and metabolic parameters in pregnant rats. J Matern Fetal Neonatal Med. 2011; 24:1254-1258.

6. Famurewa AC, Ufebe OG, Egedigwe CA, Nwankwo OE, Obaje GS: Virgin coconut oil supplementation attenuates acute chemotherapy hepatotoxicity induced by anticancer drug methotrexate via inhibition of oxidative stress in rats. Biomed Pharmacother. 2017; 87:437-442.

7. Alves NF, Porpino SK, Monteiro MM, Gomes ER, Braga VA: Coconut oil supplementation and physical exercise improves baroreflex sensitivity and oxidative stress in hypertensive rats. Appl Physiol Nutr Metab. 2015; 40:393-400.

8. Voon PT, Ng TK, Lee VK, Nesaretnam K: Virgin olive oil, palm olein and coconut oil diets do not raise cell adhesion molecules and thrombogenicity indices in healthy Malaysian adults. Eur J Clin Nutr. 2015; 69:712-716.

9. Valente FX, Candido FG, Lopes LL, Dias DM, Carvalho SDL, Pereira PF, Bressan J: Effects of coconut oil consumption on energy metabolism, cardiometabolic risk markers, and appetitive responses in women with excess body fat. Eur J Nutr. 2018; 57:1627-1637. 
10. Cardoso DA, Moreira AS, De Oliveira GM, Raggio Luiz R, Rosa G: A coconut extra virgin oil-rich diet Increases HDL cholesterol and decreases waist circumference and body mass in coronary artery disease patients. Nutr Hosp. 2015; 32:2144-2152.

11. Jansakul C, Naphatthalung J, Pradab S, Yorsin S, Kanokwiroon K: 6 weeks consumption of pure fresh coconut milk caused up-regulation of eNOS and CSE protein expression in middle-aged male rats. Braz J Pharm Sci. 2018; 54: e17259.

12. Novella S, Dantas AP, Segarra G, Vidal-Gomez X, Mompeon A, Garabito M, Hermenegildo $\mathrm{C}$, et al.: Aging-related endothelial dysfunction in the aorta from female senescence-accelerated mice is associated with decreased nitric oxide synthase expression. Exp Gerontol. 2013; 48:1329-1337.

13. Yang G, Wu L, Jiang B, Yang W, Qi J, Cao K, Meng Q, et al.: $\mathrm{H}_{2} \mathrm{~S}$ as a physiologic vasorelaxant: hypertension in mice with deletion of cystathionine gamma-lyase. Science. 2008; 322:587-590.

14. Bhayadia R, Schmidt BM, Melk A, Homme M: Senescence-induced oxidative stress causes endothelial dysfunction. J Gerontol A Biol Sci Med Sci. 2016; 71:161-169.

15. Marchesi S, Lupattelli G, Siepi D, Schillaci G, Vaudo G, Roscini AR, Sinzinger H, et al.: Short-term atorvastatin treatment improves endothelial function in hypercholesterolemic women. J Cardiovasc Pharmacol. 2000; 36:617-621.

16. Rudolph TK, Ruempler K, Schwedhelm E, Tan-Andresen J, Riederer U, Boger RH, Maas R: Acute effects of various fast-food meals on vascular function and cardiovascular disease risk markers: the Hamburg Burger Trial. Am J Clin Nutr. 2007; 86:334-340.

17. Charan J, Kantharia ND: How to calculate sample size in animal studies?. J Pharmacol Pharmacother. 2013; 4:303-306.

18. Yorsin S, Kanokwiroon K, Radenahmad N, Jansakul C: Effects of Kaempferia parviflora rhizomes dichloromethane extract on vascular functions in middle-aged male rat. J Ethnopharmacol. 2014; 56:162-174.

19. Narayanankutty A, Mukesh RK, Ayoob SK, Ramavarma SK, Suseela IM, Manalil JJ, Kuzhivelil BT, et al.: Virgin coconut oil maintains redox status and improves glycemic conditions in high fructose fed rats. J Food Sci Technol. 2016; 53:895-901.

20. Zicker MC, Silveira ALM, Lacerda DR, Rodrigues DF, Oliveira CT, De Souza Cordeiro LM, Lima LCF, et al.: Virgin coconut oil is effective to treat metabolic and inflammatory dysfunction induced by high refined carbohydrate-containing diet in mice. J Nutr Biochem. 2019; 63:117-128.

21. Frederiks WM, Van Noorden CJ, Aronson DC, Marx F, Bosch KS, Jonges GN, Vogels MC, et al.: Quantitative changes in acid phosphatase, alkaline phosphatase and 5'nucleotidase activity in rat liver after experimentally induced cholestasis. Liver. 1990; 10:158-166.

22. Grewal R, Mahmood A: Coordinated secretion of alkaline phosphatase into serum and intestine in fat-fed rats. Indian J Gastroenterol. 2004; 23:175-177.

23. Kaplan MM: Induction of rat liver alkaline phosphatase by bile duct ligation. Yale J Biol Med. 1979; 52:69-75. 
24. Seetharam S, Sussman NL, Komoda T, Alpers DH: The mechanism of elevated alkaline phosphatase activity after bile duct ligation in the rat. Hepatology. 1986; 6:374-380.

25. Askari H, Seifi B, Kadkhodaee M: Evaluation of renal-hepatic functional indices and blood pressure based on the progress of time in a rat model of chronic kidney disease. Nephrourol. 2016; Mon 8:e37840.

26. Diwan V, Mistry A, Gobe G, Brown L: Adenine-induced chronic kidney and cardiovascular damage in rats. J Pharmacol Toxicol Methods. 2013; 68:197-207.

27. Diwan V, Gobe G, Brown L: Glibenclamide improves kidney and heart structure and function in the adenine-diet model of chronic kidney disease. Pharmacol Res. 2014; 79:104-110. 